Original Research

\title{
The Donor - Recipient Weight Ratio is a Reliable Marker for Cell Yield in Hematopoietic Stem Cell Donations
}

\author{
Wolfgang Rennert ${ }^{*}$, Katie Cormier, Samantha Sprott
}

Blood \& Marrow Collection Program, MedStar Georgetown University Hospital, 3800 Reservoir Rd NW, Washington, D.C. 20007, USA; E-Mails: rennertw@gunet.georgetown.edu; Katie.A.Cormier@gunet.georgetown.edu; Samantha.M.Sprott@Medstar.net

* Correspondence: Wolfgang Rennert; E-Mail: rennertw@gunet.georgetown.edu

Academic Editor: Haval Shirwan

Special Issue: Bone Marrow Transplantation

OBM Transplantation

2021, volume 5, issue 4

doi:10.21926/obm.transplant.2104156
Received: November 22, 2021

Accepted: December 21, 2021

Published: December 24, 2021

\begin{abstract}
Bone marrow transplants remain an import source of hematopoietic stem cells for patients suffering from specific diseases like aplastic anemia, for pediatric patients with malignant and non-malignant blood cell disorders, and for situations in which graft-versus-host disease (GvHD) is a concern. Identifying the optimal donor to achieve a $3-5 \times 10^{8} / \mathrm{kg}$ of recipient weight TNC yield may be challenging. In an analysis of 687 consecutive donors, donor and procedure characteristics were related to $\mathrm{TNC} / \mathrm{kg}$ of recipient weight using Spearman correlation coefficients as well as linear and multiple regression analysis. We found correlations between donor WBC $(r=0.17)$, donor platelet counts $(r=0.15)$, donor BMI $(r=0.10)$, and the percentage of donor estimated blood volume accessed for harvesting $(r=-0.57)$ with $\mathrm{TNC} / \mathrm{kg}$ of recipient weight. The strongest correlation existed between the donor-recipient weight ratio and the $\mathrm{TNC} / \mathrm{kg}(r=84)$. In a multivariate regression analysis, the donor-recipient weight ratio influenced the $\mathrm{TNC} / \mathrm{kg}$ of recipient weight more significantly (adjusted $\mathrm{R}^{2}=0.84$ ) than all other related variables put together. The minimal donor-recipient weight ratio associated with a TNC/kg of at least $3 \times 10^{8} / \mathrm{kg}$ of recipient weight was 0.8 (mean $3.425 ; 95 \% \mathrm{Cl} 2.01,5.8$ ). Using this donor-recipient ratio provides national bone marrow donor registries with a
\end{abstract}

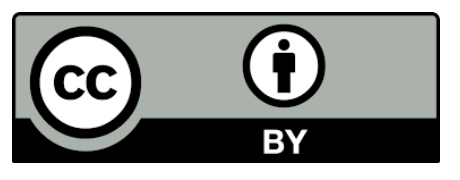

(C) 2021 by the author. This is an open access article distributed under the conditions of the Creative Commons by Attribution License, which permits unrestricted use, distribution, and reproduction in any medium or format, provided the original work is correctly cited. 
practical and simple measure to assure optimal cell yield outcomes in hematopoietic stem cell donations.

\section{Keywords}

Stem cell transplant; bone marrow donation; donor characteristics

\section{Introduction}

Allogeneic hematopoietic cell transplants (HCT) are an important part of treatment for a variety of malignant and non-malignant blood cell disorders. Today, $80 \%$ of cell grafts are retrieved through peripheral blood stem cell (PBSC) collections from unrelated donors. Bone marrow transplants, however, remain an import source of hematopoietic stem cells (HSC) for patients suffering from specific diseases like aplastic anemia, for pediatric patients with malignant and non-malignant blood cell disorders, and for situations in which graft-versus-host disease (GvHD) is a concern [1-6]. They are the focus of this study. Total nucleated cell (TNC) doses of 3-5 $\times 10^{8}$ per kilogram of recipient weight are targeted for optimal cell engraftment and recipient survival, while TNC doses below $2 \mathrm{x}$ $10^{8} / \mathrm{kg}$ are considered inadequate [7-9].

Identifying the optimal donor under these circumstances may be challenging. Studies in the past have tried to determine donor characteristics that align best with optimal total nucleated cell (TNC) yield. Donor weight, body mass index (BMI), white blood cell (WBC) count, hemoglobin (Hb) and platelet counts have correlated positively with cell yields while harvest volume, the percentage of donor's estimated blood volume harvested, female sex, and recipient weight have correlated negatively [10-15]. With a multitude of factors potentially aligning positively or negatively with harvest cell yields, national bone marrow donor registries may find it difficult to assign the best suited donor to their respective recipient.

This study aims to stratify and simplify the process by investigating if a single, easily identifiable factor - such as the donor-recipient weight ratio - can be used to facilitate the selection of wellmatched donor-recipient pairs.

\section{Materials and Methods}

\subsection{Donors}

All sequential donors who underwent a bone marrow harvest between January 2018 and October 2021 at the Georgetown University Blood and Marrow Collection Program (BMCP) were analyzed by retrospective review of data extracted manually from electronic medical records. Four donations were excluded from the analysis because their marrow was targeted for cryopreservation at a bone marrow bank without a designated recipient.

\subsection{Collection}

All donors underwent the same, highly standardized procedure using 11 gauge 6 -hole chronOS ${ }^{\mathrm{TM}}$ needles by DePuy Synthes ${ }^{\circledR}$ through bilateral single access points along the posterior iliac crest 
under general anesthesia. Marrow was retrieved in 10-15 $\mathrm{ml}$ aliquots and 3 advancements through the same needle insertion site, before redirecting the harvest needle. Intra-operative TNC (ioTNC) counts were taken after $600 \mathrm{ml}$ of collection to estimate the total volume of marrow required. Donor total blood volumes (BV) were estimated mathematically prior to the procedure using the Nadler formula ( $B V=0.3669 x$ height in meters ${ }^{3}+0.03219 x$ weight in $\mathrm{kg}+0.6041$ for males; $B V=0.3561 \mathrm{x}$ height $^{3}+0.03308 \times$ weight +0.1833 for females) [16], and harvest volumes were restricted to the lower number of $20 \mathrm{ml} / \mathrm{kg}$ of donor weight or $1,500 \mathrm{ml}$ total for men, and $18 \mathrm{ml} / \mathrm{kg}$ or $1,500 \mathrm{ml}$ for women respectively. The $1,500 \mathrm{ml}$ threshold was exceeded in some cases of donors with high BMI to satisfy TNC requests, as long as harvest volumes stayed within the $20 \mathrm{ml} / \mathrm{kg}$ limit for men and $18 \mathrm{ml} / \mathrm{kg}$ for women.

\subsection{Statistical Analysis}

The primary outcome variable of interest was the TNC yield per kg of recipient weight. Secondary outcomes included a determination of the size of influence donor characteristics had on the variance of $\mathrm{TNC} / \mathrm{kg}$ of recipient weight. Anthropometric and hematological donor characteristics were summarized using mean and range for continuous variables. The association between donor characteristics and $\mathrm{TNC} / \mathrm{kg}$ of recipient weight was analyzed by simple and multivariate linear regression models. TNC counts and continuous variables were log-transformed to produce normally distributed residuals and facilitate interpretation and graphic representation. $R^{2}$ were computed for each variable. Backward logistic elimination was applied to incorporate all variables with a conceivable effect on the outcome $(\mathrm{TNC} / \mathrm{kg})$ using $95 \%$ confidence intervals after analysis of variance inflation factors to control for collinearity between variables. Two-sided $p$ values of less than 0.05 were considered statistically significant. Data analyses were performed using Stata ${ }^{\circledR} 16^{\text {th }}$ edition statistical software.

\section{Results}

During the study period, 691 bone marrow harvests were collected. 687 were included in the analysis. 228 recipients were children of up to $40 \mathrm{~kg}$ of weight, while 459 recipients weighed more than $40 \mathrm{~kg}$. Overall recipient weights ranged from $3 \mathrm{~kg}$ to $145 \mathrm{~kg}$ (mean $56.6 \mathrm{~kg}$ ). Donor and procedure characteristics are summarized in table 1.

No significant differences were noted between female and male donors in important variables such as BMI, donor-recipient weight ratio and bone marrow harvest cell yield/mL, while other variables such as WBC and platelet counts, marrow volume collected, donor estimated blood volume accessed for harvesting, TNC/kg collected, and donor age showed minor differences that reached statistical significance mostly because of the large sample size. It was therefore deemed appropriate to analyze data from male and female donors jointly.

Six female donors had a $\mathrm{Hb}<11 \mathrm{~g} / \mathrm{dL}$ (1 donor had $\mathrm{Hb}<10 \mathrm{~g} / \mathrm{dL}$ ), while 2 male donors had $\mathrm{Hb}<$ $12 \mathrm{~g} / \mathrm{dL}$ on the day of the procedure. All had donated an auto-unit of blood to be re-infused after the procedure. Ten donors had platelet counts below $150\left(10^{9} / \mathrm{L}\right)$ on the day of the procedure. All had shown levels above $150\left(10^{9} / \mathrm{L}\right)$ during their clearance physical exam and were clinically healthy on the day of the procedure. The same applied to 25 donors with WBC $<4\left(10^{9} / \mathrm{L}\right)$. All had higher levels during their clearance physical, and all of them did clinically well during and after the procedure. 
Table 1 Characteristics for 687 volunteer donors and their bone marrow collection.

\begin{tabular}{|c|c|c|c|c|}
\hline & Mean & $\begin{array}{l}\text { Male (range) } \\
N=416(60.6 \%)\end{array}$ & $\begin{array}{l}\text { Female (range) } \\
\mathbf{N}=271(39.4 \%)\end{array}$ & $\begin{array}{l}P \text { male vs } \\
\text { female }\end{array}$ \\
\hline \multicolumn{5}{|l|}{ Donor characteristics } \\
\hline Age (years) & 28.8 & $28.2(18-55)$ & $29.6(18-54)$ & $0.0129 *$ \\
\hline Weight (kg) & 82.4 & $87.8(56.4-151)$ & $74.0(43-127.3)$ & $0.0000 *$ \\
\hline BMI $\left(\mathrm{kg} / \mathrm{m}^{2}\right)$ & 27.3 & $27.4(17.9-40.9)$ & $27.2(18.4-42)$ & 0.2401 \\
\hline Donor - recipient weight ratio & 2.59 & $2.43(0.49-17.42)$ & $2.84(0.41-20.43)$ & 0.2665 \\
\hline $\mathrm{Hb}(\mathrm{g} / \mathrm{dL})$ & 14.3 & $15.1(11.3-19.2)$ & $13.1(9.9-15.9)$ & $0.0000^{*}$ \\
\hline Platelet $\left(10^{9} / \mathrm{L}\right)$ & 254 & $236(102-461)$ & $281(142-571)$ & $0.0000^{*}$ \\
\hline WBC $\left(10^{9} / \mathrm{L}\right)$ & 6.43 & $6.25(2.9-14)$ & $6.71(2.9-11.9)$ & $0.0007^{*}$ \\
\hline Total estimated blood volume (L) & 5.030 & $5.544(4.079-8.172)$ & $4.242(2.650-6.543)$ & $0.0000 *$ \\
\hline \multicolumn{5}{|c|}{ Bone marrow product characteristics } \\
\hline $\begin{array}{l}\text { Total marrow volume collected } \\
(\mathrm{mL})\end{array}$ & 1,176 & $1,248(452-1,873)$ & $1,067(400-1,765)$ & $0.0000^{*}$ \\
\hline $\begin{array}{l}\text { Percent donor blood volume } \\
\text { collected }\end{array}$ & 23.3 & $22.3(6.6-39.4)$ & $24.8(7.9-37.8)$ & $0.0000 *$ \\
\hline TNC $\times 10^{8} / \mathrm{kg}$ requested & 4.9 & $4.7(2-20)$ & $5.1(2-15)$ & $0.0045^{*}$ \\
\hline TNC $\times 10^{8} / \mathrm{kg}$ collected & 6.6 & $6.2(1.7-39.2)$ & $7.2(1.6-39.7)$ & $0.0206^{*}$ \\
\hline ioTNC x $10^{6} / \mathrm{mL}$ & 23.1 & $23.6(10.1-64.7)$ & $22.3(9.0-49.0)$ & $0.0043^{*}$ \\
\hline Final TNC $\times 10^{6} / \mathrm{mL}$ & 19.0 & $19.0(8.4-40.9)$ & $19.0(8.8-40.2)$ & 0.9991 \\
\hline Total TNC $\times 10^{8}$ collected & 257 & $272(72-622)$ & 234 (86-519) & $0.0000 *$ \\
\hline
\end{tabular}

* Indicating statistical significance in Wilcoxon rank sum analysis

Transplant centers requested a mean TNC count of $4.9 \times 10^{8} / \mathrm{kg}$ of recipient weight. This threshold was met or passed in $71.9 \%$ of cases allowing for a $10 \%$ error margin. In 9 cases (1.3\%) the engraftment threshold of $2 \times 10^{8} / \mathrm{kg}$ of recipient weight was not met. The mean TNC count per $\mathrm{kg}$ of recipient weight for these donors was $1.84 \times 10^{8}(95 \% \mathrm{Cl} 1.73,1.94)$. All these cases showed a significant weight differential between a lighter donor and a heavier recipient with a weight gap averaging $47.5 \mathrm{~kg}(95 \% \mathrm{Cl} 28.9,66.1)$.

The donor-recipient weight ratio was strongly related to the $\mathrm{TNC} / \mathrm{kg}$ of recipient weight in a univariate Spearman correlation analysis $(r=0.84 ; p<0.0001)$. Positive Spearman correlation coefficients with the TNC/kg of recipient weight could also be established for donor WBC $(r=0.17$; $p<0.0001)$, donor platelet count $(r=0.15 ; p=0.0001)$, and donor BMI $(r=0.10 ; p=0.0074)$. Of note, the comparatively low R-values for these correlations indicate a much weaker correlation with $\mathrm{TNC} / \mathrm{kg}$ of recipient weight than that for the donor-recipient weight ratio. The percentage of donor's blood volume accessed for harvesting was negatively correlated with the TNC/kg $(r=-0.57 ; p<0.0001)$, while donor age, weight, hemoglobin and the size of the bone marrow collection did not correlate with the $\mathrm{TNC} / \mathrm{kg}$ of recipient weight (Figure 1). 

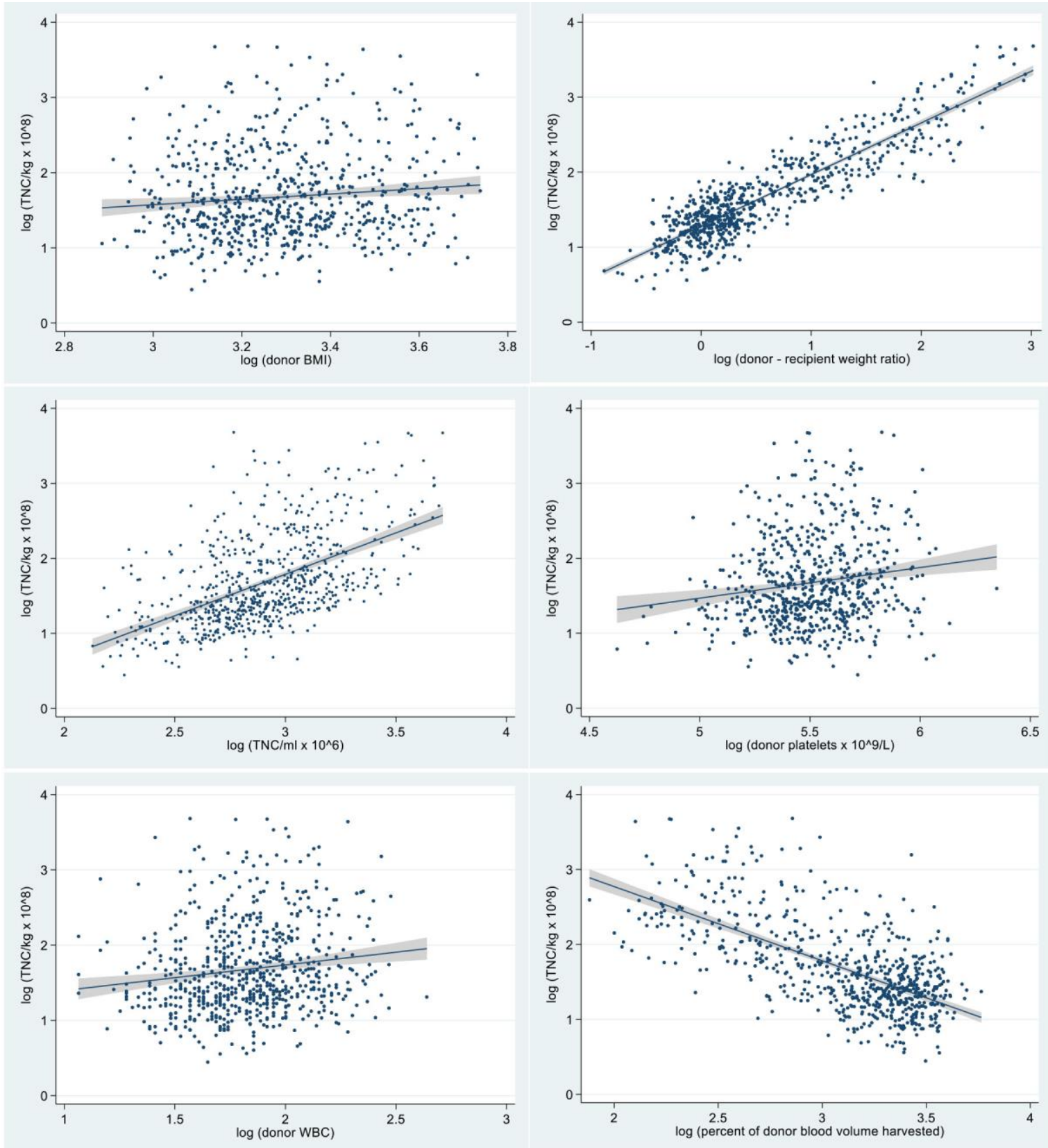

Figure 1 Logarithmically adjusted association between $\mathrm{TNC} / \mathrm{kg}$ or recipient weight and donor $\mathrm{BMI}$, donor-recipient weight ratio, procedure TNC yield per $\mathrm{ml}$, donor platelet count, donor WBC, and percentage of estimated blood volume harvested. Indicated are also line of best fit and $95 \%$ confidence intervals.

Next, the variables that were significantly related to $\mathrm{TNC} / \mathrm{kg}$ of recipient weight were subjected to a stepwise multivariate regression analysis with backward elimination after excluding collinearity between variables in an analysis of variance inflation factors (VIF). All variables had VIF $<2.3$ (mean VIF 1.55) indicating a low level of potential collinearity. The donor-recipient weight ratio on its own provided $81 \%$ of the $\mathrm{TNC} / \mathrm{kg}$ variance. Within the complete model, donor platelet count effects on $\mathrm{TNC} / \mathrm{kg}$ of recipient weight were no longer significant. The remaining variables explained $89 \%$ of $\mathrm{TNC} / \mathrm{kg}$ variance. The donor-recipient weight ratio contributed the greatest part of the $\mathrm{TNC} / \mathrm{kg}$ 
variance (84\%), more than the effects of the other variables combined. It appears that the donorweight ratio can function reliably as a predictor for $\mathrm{TNC} / \mathrm{kg}$ of recipient weight levels (Table 2).

Table 2 linear (left) and multivariate (right) regression analysis with backward elimination of donor variable effects on TNC/kg of recipient weight.

\begin{tabular}{lcccc}
\hline & Coefficient $(\mathbf{9 5 \%} \mathbf{C l} ; \mathbf{p})$ & $\mathbf{R}^{\mathbf{2}}$ & Coefficient $(\mathbf{9 5 \%} \mathrm{Cl} ; \mathbf{p})$ & Adj. $\mathbf{R}^{\mathbf{2}}$ \\
\hline $\begin{array}{l}\text { Donor-recipient } \\
\text { weight ratio }\end{array}$ & $1.71(1.64,1.77 ; 0.000)^{*}$ & 0.81 & $1.86(1.80,1.92 ; 0.000)^{*}$ & 0.84 \\
$\begin{array}{l}\text { \% donor blood } \\
\text { volume harvested }\end{array}$ & $-0.38(-0.43,-0.34 ; 0.000)^{*}$ & 0.29 & $0.18(0.16,0.21 ; 0.000)^{*}$ & 0.21 \\
TNC/ml x $10^{6}$ & $0.46(0.39,0.52 ; 0.000)^{*}$ & 0.23 & $0.34(0.31,0.37 ; 0.000)^{*}$ & 0.45 \\
Donor WBC & $0.36(0.12,0.60 ; 0.003)^{*}$ & 0.02 & $-0.11(-0.19,-0.02 ; 0.014)^{*}$ & 0.01 \\
$\begin{array}{l}\text { Donor BMI } \\
\text { Donor platelets }\end{array}$ & $0.10(0.02,0.19 ; 0.013)^{*}$ & 0.01 & $-0.11(-0.13,-0.07 ; 0.000)^{*}$ & 0.08 \\
Full model & $0.01(0.00,0.02 ; 0.002)^{*}$ & 0.01 & & \\
\hline
\end{tabular}

* Indicates statistically significant correlation

To establish a minimum donor-recipient weight ratio for a reliable prediction of adequate $\mathrm{TNC} / \mathrm{kg}$ of recipient weight, four donor-recipient weight ratio categories were analyzed that can be easily applied by national bone marrow donor registries (Table 3). A median TNC/kg of recipient weight of at least $3 \times 10^{8}$ could only be achieved with a donor-recipient weight ratio above 0.8 . At this level only $2.5 \%$ of cases did not achieve the minimum of $2 \times 10^{8} / \mathrm{kg}$ required for engraftment.

Table $3 \mathrm{TNC} / \mathrm{kg}$ of recipient weight for different donor-recipient weight ratios.

\begin{tabular}{llll}
\hline Donor-recipient weight ratio & $\begin{array}{l}95 \% \mathrm{Cl} \\
\mathrm{NCx} 10^{8} / \mathrm{kg}\end{array}$ & $\begin{array}{l}90 \% \mathrm{Cl} \\
\mathrm{NCx} 10^{8} / \mathrm{kg}\end{array}$ & $\begin{array}{l}\text { Median } \\
\mathrm{NCx} 10^{8} / \mathrm{kg}\end{array}$ \\
\hline$\leq 0.6(\mathrm{n}=6)$ & $1.74-1.98$ & $1.9-1.93$ & 1.915 \\
$>0.6-\leq 0.8(\mathrm{n}=51)$ & $1.88-5.1$ & $1.99-4.6$ & 2.84 \\
$>0.8-\leq 1(\mathrm{n}=104)$ & $2.01-5.8$ & $2.21-5.39$ & 3.425 \\
$>1(\mathrm{n}=525)$ & $2.02-39.4$ & $2.04-39.21$ & 5.58 \\
Total $(\mathrm{n}=686)$ & $1.74-39.4$ & $1.75-39.21$ & 4.7 \\
\hline
\end{tabular}

\section{Discussion}

The successful engraftment and survival of HLA-matched recipients depend to some extend on the number of hematopoietic stem cells transplanted. TNC counts of $3-5 \times 10^{8}$ per $\mathrm{kg}$ of recipient weight have been established as optimal [7-9, 17]. Overall, cell yields achieved through bone marrow harvesting has declined over the recent years. Prokopishyn et al. [18] reported fewer centers performing sufficient procedure numbers to maintain previously achieved TNC yield standards. Donor characteristics associated with higher cell yields include donor weight $[10,14]$ and BMI $[19,20]$, donor WBC [19-21] and platelet counts [11, 22], while female sex [15, 19], increasing 
age [21], higher harvest volumes [10,13-15] and higher percentages of blood volume harvested [14] were associated with lower cell yields.

While many studies focus on the TNC yield achieved in bone marrow harvests, few studies relate these to recipient requirements. Anthias et al. [13] reported that donors weighing less than their recipients are less likely to meet a goal of $4 \times 10^{8}$ cells $/ \mathrm{kg}$ or recipient weight. What is missing to date is a practical and easily applicable guideline for national bone marrow donor registries to select the optimal donor for a respective HLA-matched recipient. We believe to have established a standard of reasonable certainty for the prediction of a $3 \times 10^{8}$ TNC per kg of recipient weight applying a minimum donor-recipient weight ratio of 0.8 . In our analysis the donor-recipient weight ratio influenced TNC per kg counts far more than all the other potentially related factors taken together.

The influence of some factors may be transient. For example, the role of WBC and platelet counts on hematopoiesis appear to depend on cytokine interactions between granulopoiesis, thrombopoiesis and hematopoietic progenitor cells in closely related respective stem cell niches within the bone marrow [23-29]. These interactions vary with the individual's exposure to environmental stimuli $[30,31]$. Other factors like the donor's BMI appeared to have a positive influence on achieved cell counts when looked at individually. The effect reversed to a negative influence when analyzed together with other factors in a multivariate analysis.

This study is a single center study from the largest bone marrow harvest center associated with the National Marrow Donor Program in the United States. All procedures were performed by a small cadre of dedicated trained physicians and nurse practitioners following the same technical procedural standards and protocols. As a result, inter-center variations could be eliminated, and inter-individual variations kept to a minimum.

\section{Conclusion}

Assigning the best possible donor to an HLA-matched stem cell recipient is a difficult task for matching programs and donor centers. Multiple donor characteristics have been suggested to facilitate the selection, but simple and practical guidelines are missing for donor selection. We suggest using a donor-recipient weight ratio of 0.8 or higher as a reliable and easily applicable marker to predict a cell yield of at least $3 \times 10^{8} / \mathrm{kg}$ of recipient weight.

\section{Author Contributions}

All authors contributed to the conceptualization and implementation of the research.

\section{Funding}

The research does not have external funding sources.

\section{Competing Interests}

The authors have declared that no competing interests exist. 


\section{References}

1. Alousi A, Wang T, Hemmer MT, Spellman SR, Arora M, Couriel DR, et al. Peripheral blood versus bone marrow from unrelated donors: Bone marrow allografts have improved long-term overall and graft-versus-host disease-free, relapse-free survival. Biol Blood Marrow Transplant. 2019; 25: 270-278.

2. Amouzegar A, Dey BR, Spitzer TR. Peripheral blood or bone marrow stem cells? Practical considerations in hematopoietic stem cell transplantation. Transfus Med Rev. 2019; 33: 43-50.

3. Georges GE, Doney K, Storb R. Severe aplastic anemia: Allogeneic bone marrow transplantation as first-line treatment. Blood Adv. 2018; 2: 2020-2028.

4. Keesler DA, Martin AS, Bonfim C, Seber A, Zhang MJ, Eapen M. Bone marrow versus peripheral blood from unrelated donors for children and adolescents with acute leukemia. Biol Blood Marrow Transplant. 2018; 24: 2487-2492.

5. Mehta RS, de Latour RP, DeFor TE, Robin M, Lazaryan A, Xhaard A, et al. Improved graft-versushost disease-free, relapse-free survival associated with bone marrow as the stem cell source in adults. Haematologica. 2016; 101: 764-772.

6. Bacigalupo A, Giammarco S, Sica S. Bone marrow transplantation versus immunosuppressive therapy in patients with acquired severe aplastic anemia. Int J Hematol. 2016; 104: 168-174.

7. Kałwak K, Porwolik J, Mielcarek M, Gorczyńska E, Owoc-Lempach J, Ussowicz M, et al. Higher $\mathrm{CD} 34+$ and CD3+ cell doses in the graft promote long-term survival, and have no impact on the incidence of severe acute or chronic graft-versus-host disease after in vivo T cell-depleted unrelated donor hematopoietic stem cell transplantation in children. Biol Blood Marrow Transplant. 2010; 16: 1388-1401.

8. Heimfeld S. Bone marrow transplantation: How important is CD34 cell dose in HLA-identical stem cell transplantation? Leukemia. 2003; 17: 856-858.

9. Zaucha-Prażmo A, Sadurska E, Pieczonka A, Goździk J, Dębski R, Drabko K, et al. Risk factors for transplant outcomes in children and adolescents with non-malignant diseases following allogeneic hematopoietic stem cell transplantation. Ann Transplant. 2019; 24: 374-382.

10. Kao RH, Li CC, Shaw CK, Wang TF, Chu SC, Chen SH, et al. Correlation between characteristics of unrelated bone marrow donor and cell density of total nucleated cell in bone marrow harvest. Int J Hematol. 2009; 89: 227-230.

11. Fettah A, Özbek N, Özgüner $M, A z ı k F$, Işık $P, A v c ı ~ Z$, et al. Factors associated with bone marrow stem cell yield for pediatric allogeneic stem cell transplantation: The impact of donor characteristics. Pediatr Transplant. 2017; 21: e12841.

12. Kalin J, Nguyen AT, Oshrine B. Donor characteristics and intraoperative total nucleated cell count influence hematopoietic progenitor cell yield of healthy donor bone marrow grafts. Pediatr Blood Cancer. 2021; 68: e28902.

13. Anthias C, Billen A, Arkwright R, Szydlo RM, Madrigal JA, Shaw BE. Harvests from bone marrow donors who weigh less than their recipients are associated with a significantly increased probability of a suboptimal harvest yield. Transfusion. 2016; 56: 1052-1057.

14. Rennert W, Sobh L, Cormier K, Smith J, Gonzalez C. The impact of donor total estimated blood volume on nucleated cell yield in bone marrow harvests for hematopoietic stem cell transplantation. Transfusion. 2021; 61: 1533-1541. 
15. Getta BM, Tong D, Deren S, Huang G, Hogg M, Collins D, et al. Pre- and post-bone marrow harvest anaemia is associated with lower CD34+ stem cell collection, high harvest volume and female gender. Intern Med J. 2020; 50: 299-306.

16. Nadler SB, Hidalgo JU, Bloch T. Prediction of blood volume in normal human adults. Surgery. 1962; 51: 224-232.

17. Fagioli F, Quarello P, Pollichieni S, Lamparelli T, Berger M, Benedetti F, et al. Quality of harvest and role of cell dose in unrelated bone marrow transplantation: An Italian bone marrow donor registry-gruppo Italiano trapianto di midollo osseo study. Hematology. 2014; 19: 1-9.

18. Prokopishyn NL, Logan BR, Kiefer DM, Sees JA, Chitphakdithai P, Ahmed IA, et al. The concentration of total nucleated cells in harvested bone marrow for transplantation has decreased over time. Biol Blood Marrow Transplant. 2019; 25: 1325-1330.

19. Bouwmeester W, Fechter MM, Heymans MW, Twisk JW, Ebeling LJ, Brand A. Prediction of nucleated cells in bone marrow stem cell products by donor characteristics: A retrospective single centre analysis. Vox Sang. 2010; 98: e276-e283.

20. Rimondo A, Bramanti S, Crocchiolo R, Giordano L, Sarina B, Morabito L, et al. Bone marrow donor-related variables associated with harvest outcome in HLA-haploidentical transplantation with postinfusion cyclophosphamide. Vox Sang. 2016; 111: 93-100.

21. Wang YT, Zhao XY, Zhao XS, Xu LP, Zhang XH, Wang Y, et al. The impact of donor characteristics on the immune cell composition of mixture allografts of granulocyte-colony-stimulating factormobilized marrow harvests and peripheral blood harvests. Transfusion. 2015; 55: 2874-2881.

22. Pahwa D, Sharma RR, Marwaha N. Predictors of mononuclear cell yield in patients undergoing autologous mononuclear stem cell therapy in non-haemopoietic degenerative disorders. Indian J Hematol Blood Transfus. 2018; 34: 282-293.

23. Nomura S, Inami N, Kanazawa S, Iwasaka T, Fukuhara S. Elevation of platelet activation markers and chemokines during peripheral blood stem cell harvest with G-CSF. Stem Cells. 2004; 22: 696-703.

24. Avecilla ST, Hattori K, Heissig B, Tejada R, Liao F, Shido K, et al. Chemokine-mediated interaction of hematopoietic progenitors with the bone marrow vascular niche is required for thrombopoiesis. Nat Med. 2004; 10: 64-71.

25. Boulais PE, Frenette PS. Making sense of hematopoietic stem cell niches. Blood. 2015; 125: 2621-2629.

26. Kaushansky $\mathrm{K}$, Zhan $\mathrm{H}$. The regulation of normal and neoplastic hematopoiesis is dependent on microenvironmental cells. Adv Biol Regul. 2018; 69: 11-15.

27. Kiel MJ, Yilmaz ÖH, Iwashita T, Yilmaz OH, Terhorst C, Morrison SJ. SLAM family receptors distinguish hematopoietic stem and progenitor cells and reveal endothelial niches for stem cells. Cell. 2005; 121: 1109-1121.

28. Fibbe WE, Willemze R. The role of interleukin-1 in hematopoiesis. Acta Haematol. 1991; 86: 148-154.

29. Vacek A, Hofer M, Schneiderová H, Svoboda J. Ultrafiltered pig leukocyte extract (UPLE, $I \mathrm{MUNOR}^{\circledR}$ ) potentiates hematopoiesis-stimulating effects of G-CSF in vitro and improves the outcome of treatment of hematopoietic radiation damage in mice with G-CSF. Immunopharmacol Immunotoxicol. 2005; 27: 647-659.

30. Ter Horst R, Jaeger M, Smeekens SP, Oosting M, Swertz MA, Li Y, et al. Host and environmental factors influencing individual human cytokine responses. Cell. 2016; 167: 1111-1124. 
31. Schirmer M, Kumar V, Netea MG, Xavier RJ. The causes and consequences of variation in human cytokine production in health. Curr Opin Immunol. 2018; 54: 50-58.

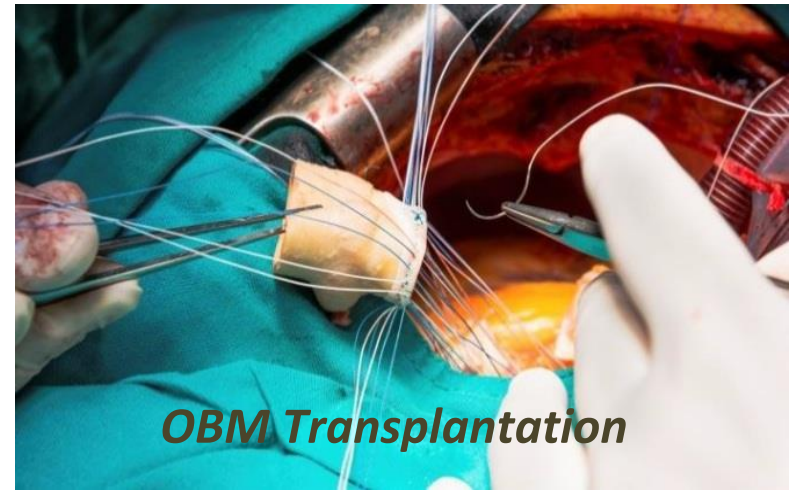

Enjoy OBM Transplantation by:

1. Submitting a manuscript

2. Joining in volunteer reviewer bank

3. Joining Editorial Board

4. Guest editing a special issue

For more details, please visit:

http://www.lidsen.com/journals/transplantation 